\title{
GLOBALISASI, PELAYARAN-PERDAGANGAN DAN DIVERSITAS POPULASI: STUDI SISA MANUSIA SITUS LERAN, REMBANG, JAWA TENGAH
}

\section{GLOBALIZATION, MARITIME TRADE, AND POPULATION DIVERSITY: STUDY ON HUMAN REMAINS FROM LERAN SITE, REMBANG, CENTRAL JAVA}

\author{
Sofwan Noerwidi \\ Balai Arkeologi Daerah Istimewa Yogyakarta \\ sofwan.noerwidi@kemdikbud.go.id
}

\begin{abstract}
The issue of globalization is booming recently, but it is not really a new thing in the history of human civilization. However, the issue of globalization in the past, -particularly in Archaeological perspective- is not too much discussed among social sciences in Indonesia. This paper aims to open the isolation by understanding the processes of globalization and its correlation to the maritime trade through archaeological data based on human remains from Leran burial site, Rembang, Central Java. Research method used in this paper is Bioarchaeological approach based on dental metric and non-metric characters analysis which performed to determine the biological affinity of Leran people in comparison with some samples from surrounding area. The result could be seen that the Leran population has a fairly diverse biological affinity which correlated to the strategic position of this site in the ancient global network of maritime trade.
\end{abstract}

Keyword: Globalization, maritime trade, population diversity, Leran burial site, north coast of Java.

\begin{abstract}
ABSTRAK
Isu globalisasi yang saat ini sedang marak dibicarakan, sesungguhnya bukan hal yang baru dalam sejarah peradaban manusia. Namun, studi mengenai globalisasi dalam perspektif masa lampau khususnya arkeologi, sampai saat ini tidak banyak didiskusikan di antara ilmu-ilmu sosial di Indonesia. Tulisan ini bertujuan untuk memahami proses globalisasi yang berhubungan dengan pelayaran dan perdagangan maritim melalui data arkeologis, berupa sisa rangka manusia dari situs Leran, Rembang, Jawa Tengah. Metode penelitian yang digunakan adalah pendekatan bioarkeologis melalui analisis karakter metrik dan non-metrik gigi geligi untuk mengetahui afinitas biologis manusia Leran dalam perbandingannya dengan beberapa sampel populasi dari kawasan sekitarnya. Hasilnya dapat diketahui bahwa populasi Leran memiliki diversitas afinitas biologis yang cukup beragam berhubungan dengan posisi strategis situs tersebut dalam jaringan perdagangan maritim global masa lampau.
\end{abstract}

Kata Kunci: Globalisasi, Pelayaran-Perdagangan, Diversitas Populasi, Situs Leran, Pantura Jawa.

Tanggal Masuk : 12 Mei 2017

Tanggal Diterima : 01 November 2017 


\section{PENDAHULUAN}

Secara garis besar, globalisasi adalah sebuah proses integrasi global yang terjadi karena pertukaran orang, produk, ide, pemikiran, pandangan dan aspekaspek kebudayaan lainnya (AlRodhan dan Stoudmann, 2006: 5). Istilah globalisasi mulai marak sejak tahun 1990an ketika terjadi loncatan perkembangan telekomunikasi dan transportasi, sehingga banyak ahli yang berpendapat bahwa globalisasi berawal di era peradaban modern (Kumar, 2009: 11). Namun demikian, beberapa pakar lainnya berusaha untuk melacak sejarah globalisasi hingga ke masa yang lebih lampau (Gills dan Thompson, 2006: 10).

Beberapa ahli menyatakan bahwa globalisasi terjadi sejak zaman penemuan dan pelayaran orang Eropa ke "Dunia Baru" (Flynn dan Giráldez, 2006: 208). Namun, nyatanya manusia telah berinteraksi dalam kisaran jarak jauh selama ribuan tahun. Salah satu contoh yang fenomenal adalah Jalur Sutra yang merupakan jembatan darat antara Asia, Afrika, dan Eropa. Proses globalisasi pada zaman pertengahan ini menyebabkan banyak perubahan pada kebudayaan, khususnya di belahan "Dunia Lama" (Foltz, 2016: 82).

Ada pula pakar yang mencatat terjadinya globalisasi pada milenium menjelang Masehi (Paul, 2011: 89). Fenomena globalisasi pada masa lampau ini dikenal dengan istilah globalisasi kuna. Proses tersebut dipandang sebagai suatu fase dalam sejarah globalisasi yang mengacu pada peristiwa dan perkembangan globalisasi sejak masa awal munculnya peradaban sampai kira-kira tahun 1600-an (Bayly, 2005: 14). Globalisasi kuna ini mengakibatkan banyak perubahan pada peradaban bangsa- bangsa di dunia. Pemikiran, agama, bahasa, kesenian, dan aspek budaya lainnya menyebar dan bercampur ketika masing-masing kawasan bertukar barang dan ide, bahkan juga diikuti dengan arus perpindahan manusia atau migrasi (Hoerder, 2002: 16; MeilinkRoelofsz, 2012: 173).

Banyak para ahli yang melihat proses globalisasi dari sudut pandang antropologis, sosiologis, dan historis, seperti misalnya Albrow dan King (1990), Reid (1993), O'Rourke dan Williamson (2001), serta Lewellen (2002). Namun tidak banyak sebuah proses globalisasi dilihat dari perspektif arkeologis. Padahal, sudut pandang ini mampu memberikan bukti fisik (material) mengenai fenomena yang terjadi pada masa lampau tersebut, seperti misalnya migrasi Out of Afrika (Bellwood, 2013: 48-50; 67-68). Oleh karena itu, maka perlu untuk melakukan studi tentang globalisasi masa lampau melalui tinggalan budaya material yang tersisa (Gonzalo, 2006: 222-223).

Salah satu cara untuk melacak jejak globalisasi adalah dengan melakukan penelitian pada situs-situs yang berada di kawasan strategis dalam pelayaran dan perdagangan. Di Pulau Jawa, situssitus tersebut berada di sepanjang dataran alluvial pantai utara yang berupa situs-situs kubur. Penelitian situs kubur di kawasan ini telah dimulai sejak dilaporkannya situs kubur tempayan Anyer, Banten pada tahun 1954. Satu tahun kemudian, situs ini diekskavasi oleh H.R. van Heekeren dan Basuki pada tahun 1955 (Heekeren, 1958: 80). Penelitian situs kubur tempayan Anyer baru digiatkan lagi setelah ditemukannya petunjuk berupa pecahan tempayan serta tulangtulang manusia pada tahun 1976. 
Soejono (1997) menempatkan situs kubur tempayan Anyer pada masa perundagian, kemudian van Heekeren berpendapat bahwa tradisi penguburan tempayan ini muncul pada sekitar 200-500 M (Sukendar et. al., 1982: 1).

Di Jawa Tengah pada tahun 1977 ditemukan situs kubur tempayan Plawangan yang terletak $27 \mathrm{~km}$ di sebelah timur Kabupaten Rembang. Situs ini berjarak sekitar $500 \mathrm{~m}$ dari garis pantai, pada suatu tempat yang cukup landai di ketinggian $4 \mathrm{~m}$ dpl. Penelitian di situs Plawangan telah dilakukan pada tahun 1977, dan 1978 hingga 1993. Pertanggalan dari situs ini berdasarkan analisis $\mathrm{C}-14$ adalah 400 M (Bintarti, 2000: 75). Hasilhasil ekskavasi menunjukkan beraneka artefak yang dibuat dari tanah liat, logam, batuan, cangkang moluska, tulang binatang, dan manik-manik (Prasetyo, 1994/1995: 2-3). Berdasarkan pada temuan tersebut maka dapat diketahui bahwa situs Plawangan merekam jejak kontak budaya dengan dunia luar sejak 1600 tahun yang lampau.
Di Jawa Barat ditemukan situs Batujaya, yang terletak di sebelah timur bagian hilir aliran Sungai Citarum di Kabupaten Karawang. Situs ini ditemukan oleh Jurusan Arkeologi, Universitas Indonesia pada tahun 1985. Situs Batujaya merupakan situs kompleks percandian Buddha yang diduga berasal dari masa periode awal peradaban Nusantara. Penelitian kerjasama yang dilakukan antara Puslitarkenas dengan l'École française d'Extrême-Orient, Perancis pada tahun 2003-2006 telah menemukan sedikitnya 30 kubur. Pertanggalan karbon dari situs ini mengindikasikan bahwa kubur-kubur tersebut berasal dari abad 1 SM - 3 M. (Manguin dan Indradjaja, 2011: 129-130). Anyer dan Batujaya merepresentasikan situs-situs yang terlibat dengan jaringan pertukaran global berdasarkan temuan tembikar Arikamedu di kedua situs tersebut yang berasal dari India.

Baru-baru ini ditemukan situs kubur kuna di Desa Leran, Kecamatan Sluke, Kabupaten Rembang. Situs yang dinamakan

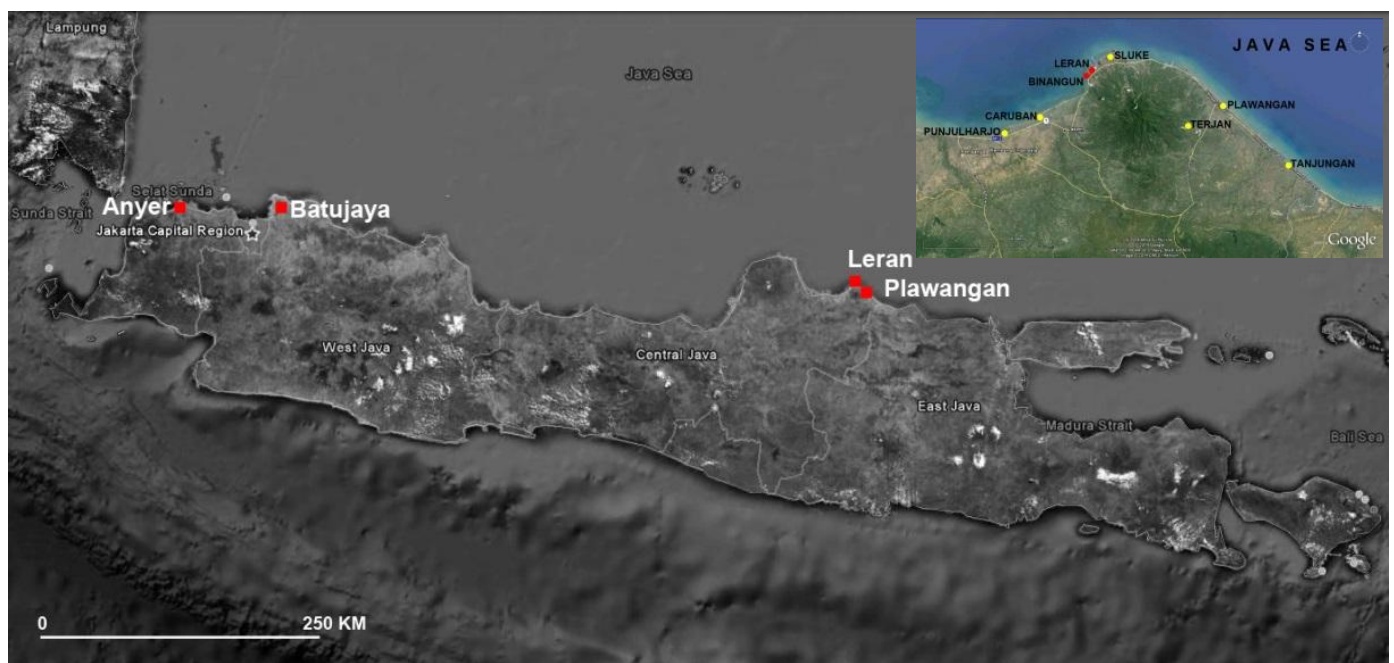

Gambar 1. Peta Distribusi Situs-Situs Kubur di Rembang (inset) dan di Pantai Utara Jawa (Sumber: Google Earth, dengan modifikasi) situs Leran ini berada di tepi pantai utara Jawa tengah. Situs Leran berjarak sekitar $10 \mathrm{~km}$ di sebelah barat situs Plawangan. Situs Leran dilaporan oleh masyarakat lokal 
kepada Balai Arkeologi D.I. Yogyakarta saat dilakukan penelitian untuk mengungkap pola permukiman masyarakat pendukung situs kubur Plawangan pada tahun 2012 (Kasnowiharjo, 2013: 3). Sebelumnya, di Kabupaten Rembang juga pernah ditemukan situs-situs kubur tepi pantai lainnya yang tersebar di sekitar situs Leran (lihat Gambar 1), seperti Bonang, Terjan, Caruban, dan Sluke (Sukendar dan Due Awe, 1981: 6). Sehubungan dengan isu globalisasi dan pelayaran perdagangan pada masa lampau, seharusnya studi rangka manusia dari situs-situs arkeologis dapat mengungkapkan heterogenitas populasi pendukungnya yang disebabkan oleh aliran perpindahan ide, budaya materi, dan manusia antar berbagai kawasan yang saling berinteraksi. Namun, sampai saat ini jarang dilakukan studi mengenai hal tersebut, khususnya di Indonesia. Berdasarkan

pada penemuan di situs Leran, maka tujuan utama tulisan ini berusaha untuk memahami proses globalisasi pada masa lampau melalui sisa rangka manusia dari situs tersebut. Secara bertahap, tulisan ini akan menampilkan informasi biologis dan kultural dari rangka-rangka yang ditemukan melalui data anatomi tersisa. Selain itu, tulisan ini merupakan pembaharuan terhadap analisis biokultural yang pernah dilakukan Noerwidi (2014), karena belum berhasil mengungkap informasi biokultural secara lengkap dan belum diketahui heterogenitas populasi pendukung situs tersebut.

Secara khusus, penelitian ini bertujuan untuk mengungkap keragaman afinitas biologis dengan menggunakan karakter metrik dan non-metrik gigi geligi manusia situs Leran, dan perbandingannya dengan beberapa sampel dari situs arkeologis maupun populasi terkini di kawasan sekitarnya.

Berdasarkan posisinya yang sangat strategis berada di tepi pantai utara Jawa dan terkait erat dengan jaringan perdagangan maritim,situs Leran diasumsikan merekam intrusi populasi yang mungkin terjadi pada suatu periode tertentu. Hasil kajian ini diharapkan dapat berkontribusi untuk memahami proses globalisasi dan jaringan global regional perdagangan maritim pada masa lampau berdasarkan keragaman populasi komunitas pendukungnya. Beberapa situs yang merefleksikan jaringan perdagangan maritim juga terdapat di pantai timur Sumatra dan pantai utara Bali (Manguin, 2009: 434-484; Ardika dan Bellwood, 1991: 221-232; Calo et al., 2015: 378-396).

\section{METODE}

Penelitian ini menggunakan pendekatan bioarkeologi, merupakan studi sisa rangka manusia (human osteology) yang berasal dari konteks arkeologis (archaeological context) (White dan Folkens, 2005: 1). Pendekatan ini dipilih karena rangka manusia yang dipelajari berasal dari konteks arkeologis yaitu situs kubur kuna Leran. Sifat penelitian dalam tulisan ini adalah deskriptif analitis, yang berusaha mendeskripsikan karakter morfologi dan morfometri yang masih tersisa dari rangka manusia situs Leran untuk kemudian dikaji dengan pendekatan bioarkeologi, salah satunya adalah metode analisis osteologi. Dua macam teknik analisis yang digunakan adalah analisis kualitatif melalui observasi morfologi anatomi, dan analisis kuantitatif melalui perhitungan morfometri rangka (White dan Folkens, 2005: 2). 
Aspek-aspek yang dibahas dalam tulisan ini adalah aspek biokultural, yang meliputi aspek biologis dan aspek kultural. Pembahasan aspek biologis mencakup estimasi usia, penentuan jenis kelamin, afinitas populasi, dan patologi atau kondisi kesehatan. Pembahasan konteks kultural akan fokus pada modifikasi budaya pada saat antemortem yang terkait dengan gigi, dan bukti budaya perimortem seperti praktek pemakaman atau tata cara penguburan. Analisis ini bertujuan untuk merekonstruksi biografi rangka manusia dari suatu situs arkeologis, seperti yang telah dilakukan oleh beberapa peneliti, (lihat Noerwidi, 2012a: 20; dan 2012b: 139).

Selanjutnya, guna merekonstruksi relasi biologis populasi Leran dengan populasi di sekitarnya, akan digunakan perbandingan karakter metrik dan non-metrik gigi geligi. Analisis nonmetrik didasarkan pada karakterkarakter khusus pada gigi-geligi rangka manusia situs Leran yang berguna sebagai bahan komparasi penilaian afiliasi individu tersebut dengan populasi manusia dari masa prasejarah maupun resen di kawasan sekitarnya. Karakter gigigeligi yang diobservasi mengacu pada studi yang dilakukan oleh Matsumura dan Oxenham (2014). Kesamaan variabel observasi yang digunakan berguna untuk menilai posisi populasi situs Leran dalam konteks kronologis dan kawasan (lihat LAMPIRAN Tabel 1). Selain variabel non-metrik, juga dilakukan observasi variabel metrik. Analisis metrik menggunakan pengukuran diameter maksimal dalam satuan millimeter pada posisi anatomis, dengan variabel:

- Mesio-Distal diameter gigigeligi PM3 hingga M2
- Bucco-Lingual diameter gigigeligi PM3 hingga M2

Variabel tersebut dipilih

karena memiliki karakter

perbandingan khas yang dapat menunjukan perbedaan antar populasi, dibandingkan dengan variabel metrik pada gigi-geligi lainnya (Noerwidi, 2012a: 21; 2012b: 140).

Guna mempresentasikan data pengukuran tersebut akan digunakan grafik statistik bivariate yaitu diagram $X Y$ plot yang bermanfaat untuk melihat distribusi korelasi dua variabel data dari masing-masing gigi-geligi yang diukur. Selain itu, juga digunakan Cluster Analysis (CA), yaitu metode statistik yang berguna untuk merangkum probabilitas utama dalam pengelompokan populasi (Holland, 2006). Perangkat lunak yang digunakan untuk mengolah data statistik dalam tulisan ini adalah PAST (PAleontological STatistic software package for education and data analysis) versi 2.13, yang merupakan perangkat lunak bersifat tanpa bayar (open source) dan khusus dikembangkan untuk mengolah data statistik dalam arkeologi (Hammer et al., 2001: 1-2).

\section{HASIL PENELITIAN}

Situs Leran berada tidak jauh di sebelah barat dari dermaga PLTU Sluke yang pembangunannya menyebabkan abrasi pantai yang hebat di sekitar area ini. Akibat dari kondisi lingkungan yang rawan bagi kelangsungan situs Leran, maka kemudian dilakukan kegiatan penyelamatan yang bertujuan untuk mengamankan potensi arkeologis situs tersebut. Ekskavasi penyelamatan hingga tahun 2013 setidaknya telah menemukan 23 rangka manusia. Tujuh fitur kubur 
yang masih baik secara kontekstual, memperlihatkan bahwa individuindividu tersebut dimakamkan dalam posisi terlentang dengan orientasi arah utara-selatan. Sampai saat ini, situs Leran telah menghasilkan temuan rangka manusia yang cukup signifikan, untuk mengungkap berbagai aspek kehidupan termasuk keragaman populasi masa lampau di pantai utara Pulau Jawa.

\section{Studi Bioarkeologis}

\section{Secara}

horisontal, persebaran sebagian besar temuan rangka di situs Leran berada di sekitar dinding tebing sisi utara lahan keluarga Pak Wardoyo yang berbatasan dengan Laut Jawa (Kasnowihardjo, 2013: 7). Berdasarkan hasil identifikasi paska ekskavasi penyelamatan tahun 2013, jumlah individu manusia (Minimum Number of Individu) yang ditemukan di situs Leran adalah dua puluh tiga (23) individu. Jumlah tersebut masih dapat terus bertambah mengingat lahan situs yang tersisa dan selamat dari abrasi Laut Jawa masih luas.

Kondisi konservasi tulang pada himpunan rangka di situs Leran menunjukkan derajat konservasi yang berbeda antara satu rangka dengan rangka lainnya. Namun, sebagian besar rangka menunjukkan kondisi tulang yang cukup baik. Berdasarkan pada hasil ekskavasi dapat diketahui pula bahwa sisa rangka manusia di situs Leran rata-rata terletak pada kedalaman 80-120 cm dari permukaan tanah saat ini, dengan jenis litologi berupa lempung coklat kehitaman dan posisi rangka di atas bedrock batu lempung tufaan (Noerwidi, 2014: 87).

Berikut ini akan dibahas aspek biologis sisa manusia dari situs Leran yang mencakup estimasi usia, penentuan jenis kelamin, perkiraan perawakannya, dan patologi atau kondisi kesehatan. Aspek kultural yang akan ditampilkan dari sisa manusia kubur kuna Leran mencakup modifikasi budaya pada saat premortem terkait tengkorak atau gigi, dan bukti budaya perimortem seperti praktek pemakaman (tata cara penguburan). Perbandingan aspek kultural juga akan dilakukan dengan catatan etnografis dari populasi Indonesia (terutama etnis Jawa) dan populasi lainnya di kepulauan Nusantara.

\section{Aspek Biologis Manusia Leran}

Berdasarkan hasil penelitian, dapat diketahui bahwa cukup banyak jumlah individu yang belum dapat diketahui jenis kelamin maupun rentang usianya. Hal ini disebabkan oleh terbatasnya materi tersisa yang dapat diidentifikasi, maupun kondisi konservasi rangka yang fragmentaris. Beberapa individu yang belum dapat ditampakkan secara keseluruhan anggota-anggota anatominya karena masih terkubur di dalam tanah, diharapkan dapat diungkap pada penelitian di masa yang akan datang.

Komposisi usia dan jenis
kelamin manusia situs Leran
bervariasi dari tingkat usia anak-
anak hingga dewasa, serta mewakili
jenis kelamin, laki-laki maupun
perempuan. Identifikasi usia dan
jenis kelamin dilakukan berdasarkan
pada derajat pertumbuhan gigi geligi
dan karakter yang melekat pada
tengkorak dengan menggunakan
metode yang dikembangkan oleh
Buikstra dan Ubelaker (1994).
Berdasarkan hasil analisis anatomi
pada materi tersisa, dapat diketahui
bahwa manusia situs Leran terdiri
dari sepuluh (10) laki-laki, empat (4)
perempuan dan sembilan (9) rangka


yang belum dapat diketahui jenis kelaminnya. Berdasarkan rentang usia menurut metode Lovejoy (1985), dapat diketahui terdapat tiga (3) anak-anak, satu (1) dewasa muda, tiga (3) dewasa menengah, lima (5) dewasa lanjut, lima (5) tua dan enam (6) individu dewasa yang belum diketahui tepat rentang usianya.

Perhitungan tinggi badan populasi Leran didasarkan pada pengukuran panjang maksimal tulang-tulang panjang (M1) menurut kategori Martin dan Saller (1957). Hasilnya kemudian diaplikasikan dalam formula yang dibangun oleh Bergman dan Hoo (1955) berdasarkan sampel populasi Jawa, dan formula Trotter (1970) berdasarkan sampel populasi Mongoloid. Berdasarkan pada hasil pengukuran tersebut maka dapat disimpulkan bahwa manusia kubur kuna Leran memiliki perawakan tinggi badan antara 161-170 cm untuk individu laki-laki, sedangkan untuk individu perempuan, memiliki perawakan tinggi badan antara 155$160 \mathrm{~cm}$. Berdasarkan pada perbandingan dengan tinggi badan manusia Jawa yang hidup saat ini, maka dapat diperkirakan bahwa populasi Leran memiliki kemiripan perawakan dengan manusia Jawa resen. Oleh karena itu maka dapat diduga bahwa manusia Jawa yang hidup saat ini memiliki hubungan genetis dengan manusia Leran. Penelitian dengan pendekatan genetika di masa datang, diharapkan dapat membantu untuk mengungkap lebih jauh masalah ini.

\section{Aspek Kultural Manusia Leran}

Secara teknis, sistem penguburan di situs Leran menunjukkan penguburan primertunggal tanpa bekal kubur, dalam lubang sempit pada kedalaman 80-
$120 \mathrm{~cm}$ dari permukaan tanah saat ini. Rangka-rangka dimakamkan dengan orientasi penguburan utaraselatan, dengan posisi kepala berada di sebelah utara. Orientasi penguburan dengan posisi kepala seperti ini sangat menarik, karena berorientasi ke arah laut yang pada beberapa masyarakat tradisional Austronesia, diyakini sebagai arah kedatangan nenek moyang mereka (Kasnowiharjo, 2013: 9). Namun, posisi rangka miring ke kanan, ke arah barat (Ka'bah ?), dengan posisi kedua tangan bersedekap dan keduanya diletakan di atas dada. Posisi rangka yang demikian ini mengingatkan tradisi pemakaman pada masyarakat yang telah memeluk kepercayaan Islam (Noerwidi, 2014: 89). Tidak ditemukannya tanda kubur berupa jirat dan nisan, seperti yang lazim terdapat pada kubur tradisi Islam, mungkin disebabkan karena tanda kubur ini terbuat dari bahan organik, (seperti misalnya kayu) sehingga tidak terkonservasi dan ditemukan kembali di masa kini.

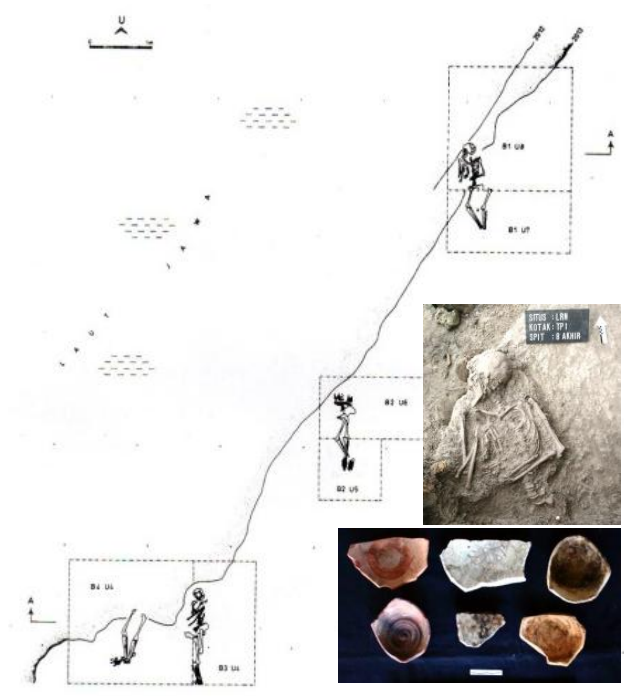

Gambar 2. Posisi Anatomis Rangka Kubur Leran (Kiri) dan Beberapa Rragmen Keramik Dinasti Yuan (Abad 13) (Kanan)

(Sumber: Balai Arkeologi D.I. Yogyakarta, Tidak Dipublikasikan) 
Teknik penguburan manusia Leran menimbulkan permasalahan kronologi budaya. Berdasarkan hasil pertanggalan dengan sampel arang menggunakan metode C14 oleh Kasnowihardjo (2013) menghasilkan umur $2.640 \pm 150 \mathrm{BP}$. Di lain pihak, berdasarkan konteks temuan arkeologis berupa fragmen-fragmen keramik yang ditemukan di situs Leran menunjukan dari periode Dinasti Yuan hingga Ming (Abad 13$15 \mathrm{M})$. Perbedaan kronologi yang cukup jauh ini disebabkan oleh aspek tafonomi kultural akibat aktifitas penggalian lubang kubur untuk menempatkan jenazah, sehingga terjadi kekacauan stratigrafi. Pertanggalan relatif Abad 13-15 M sesuai dengan periode awal perkembangan permukiman komunitas Muslim di Pulau Jawa. Namun demikian, di masa yang akan datang pertanggalan situs Leran perlu dikonfirmasi menggunakan teknik pertanggalan direct dating (langsung) dengan sampel pada tulang manusia.

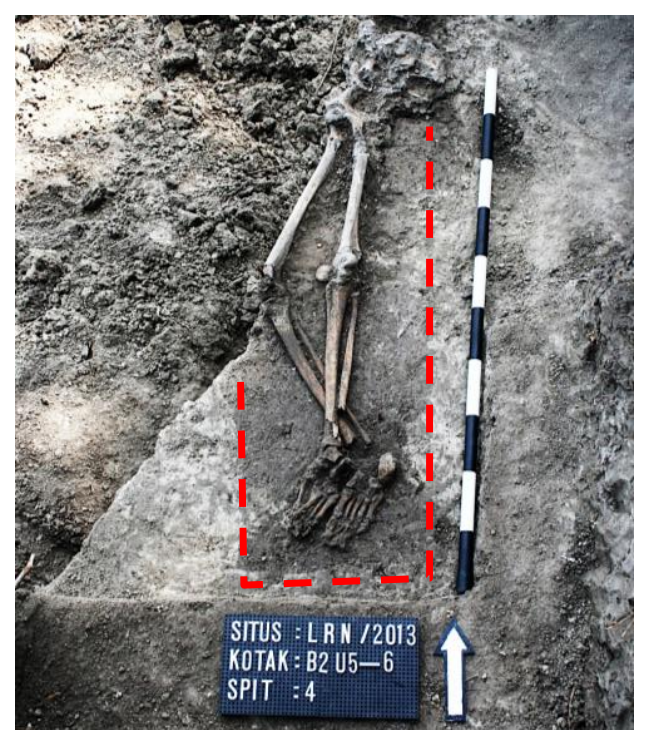

Gambar 3. Fitur Lubang Kubur yang Sempit, Tidak Memungkinkan Untuk Dilakukan

Pertanggalan dari Stratigrafi Kotak Ekskavasi (Sumber: Balai Arkeologi D.I. Yogyakarta, Tidak Dipublikasikan)
Jejak kebiasaan mengunyah Sirih (Piper betle) pinang (Areca catechu) pada manusia Leran dijumpai pada beberapa individu, salah satunya adalah pada individu Leran 13. Jejak tersebut dapat diamati pada permukaan bucal dan lingualdi beberapa gigi, khususnya gigi sisi anterior. Selain itu, manusia Leran juga melakukan tradisi mutilasi gigi bagian atas (maxilla) yaitu incisive medial dan lateral. Ada dua variasi mutilasi yang ditemukan pada manusia Leran, yaitu mutilasi lurus dan mutilasi berundak. Mutilasi lurus dilakukan dengan pemotongan lurus bagian lateral, sedangkan mutilasi berundak dilakukan dengan pemotongan bertingkat pada bagian lateral gigi (Noerwidi, 2014: 89).

Rangka yang menunjukan model mutilasi lurus adalah individu Binangun 1, sedangkan model mutilasi berundak adalah individu Leran 2. Budaya ini merupakan bukti tradisi ritual inisiasi, seperti yang masih ditemukan di beberapa etnis di Indonesia. Tradisi pengupaman gigi dan mengunyah sirih ditemukan di Indonesia dan Asia Tenggara daratan. Hal ini menunjukkan hubungan budaya antara rangka manusia Leran dengan daerahdaerah tersebut (Rooney, 1993: 27; Noerwidi 2012a: 57; 2014: 89).

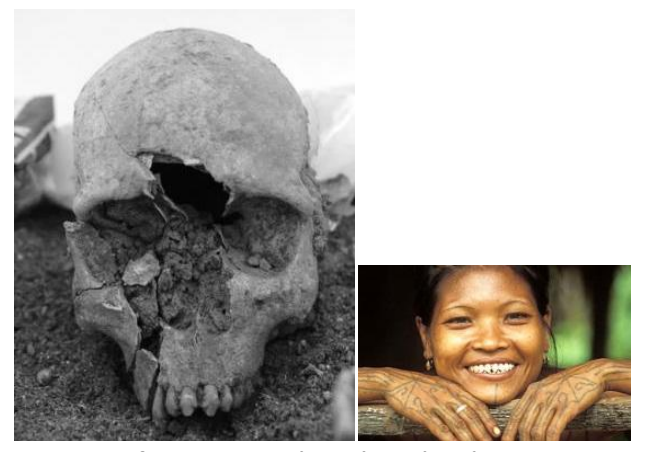

Gambar 4. Tengkorak Individu Leran 2, dengan Pola Jejak Pangur Peruncingan Gigi

Seri (Kiri), dan Tradisi yang Mirip Masih Dilakukan Orang Mentawai (Kanan) (Sumber: Noerwidi, 2014) 


\section{Afinitas Populasi Manusia Leran}

Penilaian afinitas atau relasi biologis berdasarkan rangka manusia telah menjadi sejarah yang panjang dalam bidang antopologi fisik (Armelagos et al., 1982: 305306). Guna memperkirakan derajat relasi genetis antar populasi, para ahli bekerja dalam suatu asumsi mendasar, yaitu populasi yang memperlihatkan kesamaan paling banyak adalah yang paling dekat relasi biologisnya (Larsen, 1997: 360). Ahli forensik secara tradisional menggunakan teknik analisis metrik dan non-metrik dalam melakukan penilaian jarak biologis antar populasi (Pietrusewsky, 2000: 487).

Penggunaan materi gigigeligi dirasakan paling efektif dalam penilaian hubungan antara populasi kuna dan modern karena beberapa sebab. Gigi merupakan anggota anatomi yang memiliki kondisi konservasi lebih baik dari pada tulang dalam konteks arkeologis. Gigi memperlihatkan sebuah keragaman detail anatomi yang menggambarkan komposisi genetik yang tinggi pada saat pembentukan morfologi gigi, sehingga menunjukkan perbedaan antar populasi. Faktor lingkungan, gender, dan usia hanya sedikit berpengaruh pada pembentukan morfologi gigi dibandingkan anatomi tulang lainnya (White dan Folkens, 2005: 38).

Dalam studi ini juga akan digunakan materi gigi atas maupun gigi bawah dengan menggunakan variabel non-metrik dan metrik, seperti yang telah dijelaskan pada bagian sebelumnya. Di bawah ini akan disajikan hasil analisis nonmetrik dan metrik gigi-geligi untuk menilai kedekatan relasi biologis populasi situs kubur Leran dalam perbandingan dengan populasi kuna maupun resen di sekitarnya.

\section{Karakter Non-Metrik}

Berikut ini adalah penilaian atas dua puluh satu variabel karakter non-metrik pada gigi rahang atas dan rahang bawah populasi Leran. Empat belas variabel adalah karakter dari gigi rahang atas, sedangkan tujuh variabel sisanya adalah karakter dari gigi rahang (lihat Scott, 1973). Dari jumlah 23 individu yang teridentifikasi, hanya sekitar 4 hingga 9 individu saja yang dapat dilakukan penilaian, sedangkan sisanya memiliki kondisi konservasi yang fragmentaris sehingga menyulitkan penilaian. Persentase kemunculan karakter non-metrik pada populasi Leran kemudian dibandingkan dengan kehadiran karakter serupa pada beberapa populasi di sekitar Asia Tenggara. Sebagai perbandingan, digunakan data hasil analisis dari Matsumura dan Oxenham (2014: 910).

Berdasarkan pada hasil perbandingan tersebut, maka dapat diketahui bahwa populasi Leran memiliki karakter campuran yang tidak konsisten (lihat LAMPIRAN Tabel 2). Beberapa variabel menunjukkan bahwa manusia Leran lebih dekat dengan populasi Australo-Melanesian Asia Tenggara Kepulauan dari periode awal Holosen, namun di lain pihak beberapa variabel menunjukkan bahwa populasi tersebut lebih dekat dengan populasi Mongoloid dari Asia Tenggara daratan dari periode akhir Holosen. Guna merangkum perbandingan relasi biologis manusia Leran dengan populasi di sekitarnya, maka digunakan cluster analysis yang bertujuan untuk memudahkan dan merangkum hasil penilaian afinitas populasi. Berikut ini adalah hasil cluster analysis tersebut. 
Pada cluster analysis tersebut di atas, maka dapat diketahui bahwa terdapat tiga grup utama populasi di Asia Tenggara, yaitu populasi (a) Neolitik Asia Tenggara, (b) Pre-Neolitik Asia Tenggara, dan (c) Jaman Logam Asia Tenggara. Berdasarkan pada hasil analisis ini dapat diketahui bahwa posisi populasi Leran berada pada kelompok populasi Jaman Logam, walaupun berada pada jarak percabangan yang paling luar, dan mendekati dua kelompok populasi lainnya. Hal ini mungkin disebabkan oleh campuran dari ketiga kelompok populasi tersebut yang persentasenya cukup berimbang ditemukan dalam populasi Leran. Guna memahami lebih dalam kondisi data yang menarik ini, maka kemudian dilakukan analisis metrik pada tiap individu dalam populasi Leran.
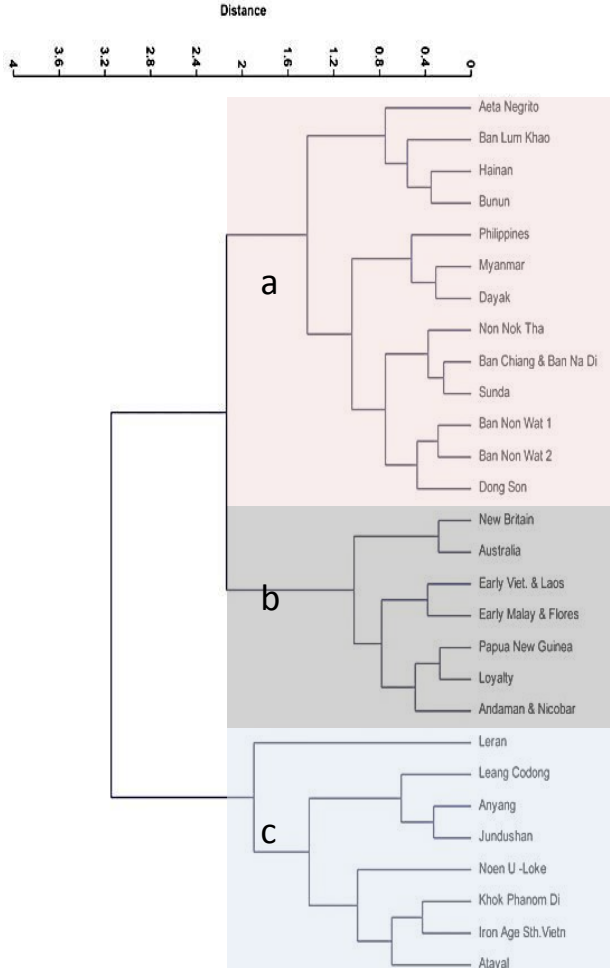

Gambar 5. Cluster Analysis Posisi Populasi Leran dalam Perbandingannya dengan Populasi di di Asia Tenggara (Sumber: Hasil Analisis Penulis)

\section{Karakter Metrik}

Analisis metrik dilakukan berdasarkan hasil pengukuran dua variabel yaitu; Mesio-Distal dan Bucco-Lingual. Gigi-geligi yang diukur adalah gigi Premolar 3 hingga Molar 2 bagian bawah (mandibular). Pada analisis metrik ini digunakan presentasi grafik dua variabel dengan nilai hasil pengukuran Mesio-Distal pada sumbu $X$ dan Bucco-Lingual pada sumbu $Y$.
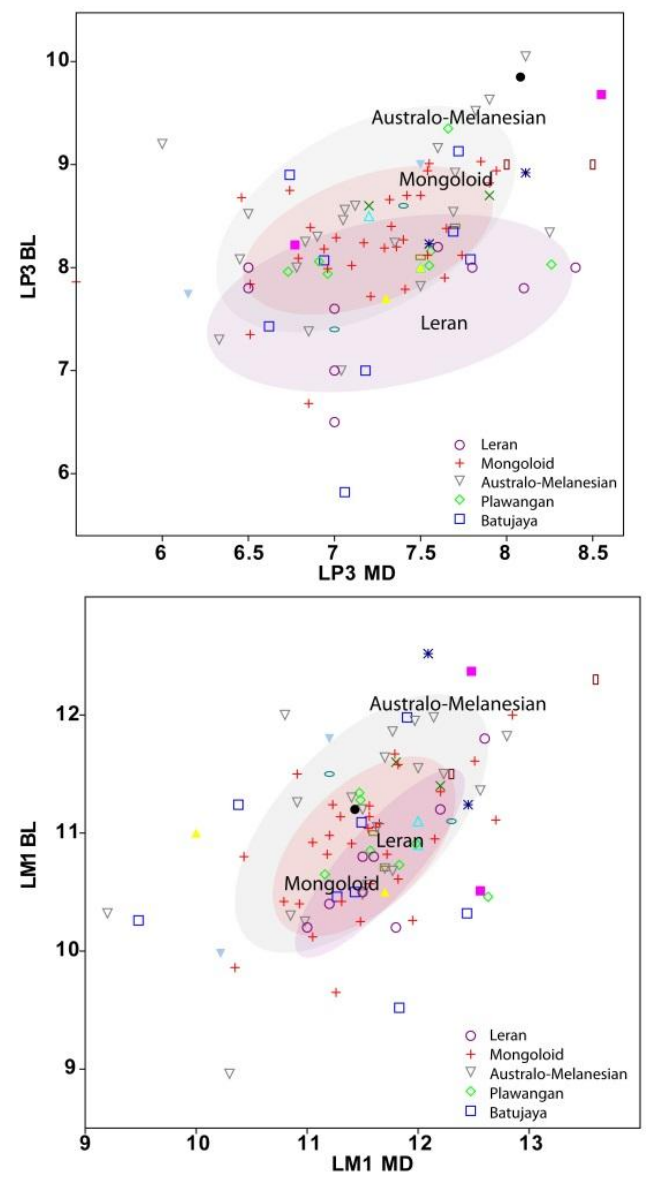

Gambar 6. Relasi 2 Variabel Pengukuran Gigi Premolar 3 (Atas) dan Molar 1 (Bawah) Manusia Leran dengan Populasi Lain di Sekitarnya

(Sumber: Hasil Analisis Penulis)

Berdasarkan hasil analisis relasi dua variabel pengukuran tersebut dapat diketahui bahwa individu-individu populasi Leran memiliki kedekatan biologis yang 
beragam dengan populasi lain di sekitarnya. Sebagai contoh ditampilkan hasil analisis pada gigi Premolar 3 dan Molar 1 (lihat Gambar 5.). Pada grafik korelasi gigi Premolar 3 dapat diketahui bahwa individu-individu populasi Leran memiliki distribusi yang sangat beragam dan tidak selaras dengan dua populasi besar di sekitarnya, yaitu Mongoloid dan AustraloMelanesia. Pada grafik korelasi gigi Molar 1 dapat diketahui bahwa distribusi gigi individu populasi Leran berada di dalam populasi Mongoloid Asia Tenggara Kepulauan.

Guna merangkum komparasi relasi dua variabel pengukuran tersebut maka digunakan cluster analysis yang berguna untuk memudahkan dan merangkum hasil penilaian afinitas populasi tersebut (Lihat LAMPIRAN Gambar 6.).

Mirip dengan hasil analisis berdasarkan data non-metrik, pada analisis klaster dengan data metrik di atas dapat diketahui bahwa terdapat empat grup utama populasi di Asia Tenggara, yaitu populasi (a) "Ramping" yang belum diketahui asal usul geografisnya, (b) AustraloMelanesia, (c) campuran antara Australo-Melanesia dengan Mongoloid, dan (d) Mongoloid. Berdasarkan pada hasil analisis ini dapat diketahui bahwa individuindividu populasi Leran terdistribusi menyebar pada keempat kelompok populasi tersebut.

Berdasarkan grafik cluster analysis dapat diketahui bahwa 4 spesimen berada dalam grup Mongoloid, 2 spesimen berada dalam grup Australo-Melanesia, 1 spesimen berada dalam grup campuran Mongoloid dengan Australo-Melanesia, dan 2 spesimen berada dalam grup "Ramping" yang belum diketahui secara pasti koneksi geografisnya. Hasil analisis ini menunjukkan bahwa populasi manusia Leran memiliki diversitas biologis yang cukup beragam dengan asal usul dari populasi geografis yang berbeda-beda.

\section{DISKUSI DAN PEMBAHASAN}

\section{Globalisasi dan Jaringan Maritim}

Asal-usul diversitas populasi Leran yang telah diketahui berdasarkan hasil analisis di atas, sangat mungkin disebabkan oleh posisi strategis situs tersebut yang berada di tepi pantai utara Pulau Jawa dan menghadap ke Laut Jawa sebagai jalur utama pelayaran perdagangan di Nusantara, atau dikenal dengan istilah Jalur Rempah. Menurut Denys Lombard (2005), Pulau Jawa sebagai bagian dari Kepulauan Nusantara, secara geografis terletak pada persilangan strategis di antara dua kutub besar kebudayaan Timur (Asia) dan Barat (Timur Tengah dan Eropa).

Posisi strategis Pulau Jawa mengakibatkan perkembangan kebudayaan di pulau ini selalu mendapat pengaruh dari budayabudaya besar kawasan lain di sekitarnya, seperti China, India, Timur Tengah, dan Eropa. Empat di antara kebudayaan besar tersebut yang pada masa lampau pernah mempengaruhi perkembangan peradaban di Kepulauan Nusantara khususnya di Pulau Jawa adalah Kebudayaan India (Hindu-Budha), Islam, Cina, dan Kolonial (Eropa) (Lombard, 2005: 3).

Pengaruh kebudayaan asing mulai masuk di Kepulauan Nusantara, setidaknya sejak awal abad Masehi dan berlanjut hingga masa kemudian. Hal ini terjadi disebabkan oleh proses globalisasi yang didukung dengan 
perkembangan teknologi transportasi pelayaran antar kawasan, serta digunakannya bahasa serumpun yang menjadi lingua-franca (bahasa perantara) bagi komunikasi antar komunitas di Kepulauan Nusantara (Tanudirjo, 2006: 85).

\section{Berdasarkan perspektif} lingustik dapat diketahui bahwa rumpun bahasa Austronesia merupakan bahasa terbesar yang digunakan di lebih dari separuh belahan dunia. Rumpun bahasa Austronesia beranggotakan sekitar 1200 bahasa, dan digunakan oleh lebih dari 350 juta penutur, dengan jumlah penutur terbesar terdiri dari bahasa Melayu, Jawa dan Tagalog (Tryon, 1995: 17-19). Robert Blust (1985) berhasil merekonstruksi kosa kata bahasa Austronesia yang berhubungan dengan teknologi perkapalan, navigasi, biota serta lingkungan laut yang berumur hingga 3500 SM. Selain itu, dari bukti etnografi juga masih dijumpai beberapa etnis tradisional di Nusantara yang mempertahankan tradisi pelayaran perdagangan jarak jauh, seperti; Sama-Bajau dan Bugis-Makassar (Sather, 1995: 255).

Perkembangan komunikasi dan transportasi meningkatkan arus pelayaran-perdagangan jarak jauh yang mendorong terjadinya proses globalisasi, sehingga membentuk jaringan antar kawasan yang melibatkan Mediterania, Asia Barat, Sub-Kontinental India, Asia Tenggara Kepulauan, Asia Tenggara Daratan dan Cina. Bukti Arkeologi yang mengindikasikan hal ini antara lain adalah; temuan cengkeh di Terqa, Eufrat berumur 3500 BP (Spriggs, 2000: 69), koin Romawi Barat Victorinus (268-270 AD) di UThong, Thailand (Glover, 1990: 4), koin Cina dan manik-manik Carnelian di Uattamdi, Maluku Utara berumur 2300 BP (Bellwood, 2000: 431-432), gerabah Rouletted IndoRoman di situs Buni (pantai utara Jawa Barat), serta gerabah Arikamedu (Tamil Nadu) dengan aksara Brahmi di Sembiran dan Pacung (Pantai Utara Bali) dari awal abad Masehi (Ardika dan Bellwood, 1991: 225-226). Temuan arkeologis tersebut mengindikasikan adanya interaksi antar kawasan yang letaknya sangat berjauhan, dari Eropa hingga Cina melalui Nusantara. Walaupun tidak membuktikan interaksi langsung, namun setidaknya menyiratkan adanya jaringan luas yang menghubungkan kawasan dunia barat dan timur termasuk Nusantara dan Pulau Jawa di dalamnya.

Melalui jaringan pelayaranperdagangan, komoditas hasil bumi dari Nusantara diperkenalkan ke dunia barat, seperti; rempahrempah, fauna eksotis, dan berbagai jenis kayu-kayuan yang langka (Dorléans, 2006: 191). Sebaliknya, barang-barang dari luar, seperti; logam, manik-manik, perhiasan batu hijau (jade), dan keramik, mulai digemari di Nusantara (Bellwood, 2000: 275-277). Selain barangbarang import, melalui jaringan global yang terjalin juga disebarkan kebudayaan sebagai pandangan hidup dan identitas baru ke Nusantara, yang pada akhirnya diserap oleh beberapa masyarakat lokal, sehingga memunculkan fenomena glokalisasi yang khas pada tiap tempatan (Bauman, 1998: 45; Tanudirjo, 2006: 86).

\section{Diversitas Populasi}

Pada saat terjadi kontak antar kelompok manusia dengan latar belakang budaya yang berbeda, terbuka pula peluang terjadinya percampuran populasi. Hal ini dapat juga terjadi karena arus 
intensif pelayaran-perdagangan yang dimanfaatkan sebagai jalur migrasi manusia (Hoerder, 2002: 16). Oleh karena itu, maka dapat disimpulkan bahwa diversitas afinitas populasi situs Leran disebabkan oleh posisi strategis situs ini yang berada pada jalur pelayaran-perdagangan Nusantara masa lampau, sehingga memungkinkan untuk terjadinya kontak antar manusia dengan latar belakang budayanya yang beragam. Temuan artefaktual yang mendukung simpulan ini adalah dengan ditemukannya beragam fragmen keramik asing (China dan Asia Tenggara) dari kurun abad 13$15 \mathrm{M}$ di situs tersebut.

Adanya arus migrasi yang terjadi pada masa sejarah melengkapi pandangan Noerwidi (2012) yang mengajukan adanya tahapan gelombang migrasi manusia dengan istilah migrasi "Multiple Migration". Setidaknya manusia mulai menghuni Pulau Jawa sesaat setelah letusan Toba "super volcano" pada 74 ribu tahun lalu, yang disusul dengan beberapa perubahan lingkungan sehingga menyebabkan terbentuknya jembatan darat yang menghubungkan pulau-pulau di Paparan Sunda dengan Asia Tenggara Daratan dan memicu migrasi manusia. Gelombang migrasi besar selanjutnya dilakukan oleh masyarakat penutur bahasa Austronesia terjadi pada awal periode neolitik sekitar 3000 tahun lalu, yang dipicu oleh faktor demografi. Pada awal abad masehi hingga masa sejarah yang lebih kemudian, seiring dengan semakin intensifnya kontak antar kawasan akibat meningkatnya pelayaranperdagangan, kemudian jaringan pelayaran-perdagangan maritim ini juga diikuti oleh arus perpindahan penduduk.

\section{KESIMPULAN}

Berdasarkan hasil studi
bioarkeologi ini, maka dapat diketahui penyebab diversitas populasi yang berhubungan dengan proses globalisasi dan pelayaranperdagangan. Diperkirakan bahwa populasi manusia situs Leran merepresentasikan jejak awal permukiman pengaruh budaya Islam di Jawa. Situs penguburan ini menggambarkan populasi komunitas campuran, antara pendatang yang berasal dari luar Jawa dan bercampur dengan pribumi Jawa yang masih menjalankan beberapa tradisi budaya Pra-Islam. Komposisi diversitas populasi situs Leran yaitu; $44 \%$ berafiliasi Mongoloid, 22\% Australo-Melanesian, 22\% grup "Ramping", dan $11 \%$ campuran Mongoloid dengan AustraloMelanesian.

Diversitas populasi manusia Leran juga menguatkan hipotesis "Multiple Migration" yang menggambarkan arus-arus tahapan gelombang migrasi manusia ke Pulau Jawa, seperti disarankan oleh Noerwidi (2012). Populasi Leran merefleksikan masih berlangsungnya arus migrasi manusia ke Pulau Jawa pada masa belakangan, saat berdirinya kerajaan Singasari-Majapahit, yang disebabkan oleh pesatnya arus pelayaran-perdagangan regional.

Bukti adanya orang asing yang menetap di Jawa telah terekam sejak masa Mataram kuna, seperti yang disebutkan dalam prasasti Warudu Kidul (922 M), kemudian pada periode Majapahit keberadaan orang asing juga masih dicatat dalam prasasti Balawi (1305 M). Berbagai kelompok etnis tersebut 
antara lain adalah; Keling, Arya, Singhala, Karnnataka, Bahlara, Cina, Campa, Mandikira, Remin, Khmer, Bebel, dan Mambang (Dwiyanto, 1993: 228; Priswanto, 2012: 22; Wahyudi dan Kuswanto, 2014: 69).

\section{SARAN/REKOMENDASI}

Prospek dari studi ini adalah masih terbukanya studi komparasi dengan populasi kuna maupun resen, guna menjawab asal usul populasi geografis yang bermigrasi ke Pulau Jawa khususnya pada masa sejarah. Populasi yang dapat dijadikan studi komparasi tersebut, seperti misalnya populasi Vietnam, Bengal, dan Timur Tengah. Selain itu juga dapat dilakukan analisis lanjutan pada bagian anatomi lainnya guna memahami berbagai aspek bioarkeologis yang belum sempat terungkap dalam studi yang masih terbatas ini, seperti misalnya studi pada bagian cranio-facial maupun anggota anatomi rangka manusia lainnya.

Diharapkan, pada masa yang akan datang semakin banyak studi bioarkeologi yang dapat berkontribusi untuk membaca gerak zaman, sehingga mampu memberikan prediksi-prediksi berdasarkan fenomena permasalahan sosial-budaya masyarakat yang sedang terjadi dan kemudian memberikan arahan yang tepat bagi proses perkembangan peradaban bangsa.

\section{UCAPAN TERIMA KASIH}

Tulisan ini didedikasikan kepada alm. Hadi Sunaryo, ahli pemetaan dan penggambaran Balai Arkeologi D.I. Yogyakarta, yang telah membuat denah situs Leran yang digunakan dalam tulisan ini. Penulis menyampaikan ucapan terimakasih sebesar-besarnya kepada Bapak Gunadi Kasnowihardjo ketua tim penelitian situs kubur kuna Leran, yang telah mengizinkan penulis untuk menganalisis dan mempublikasikan hasil penelitian ini.

Terima kasih juga penulis sampaikan kepada seluruh anggota tim penelitian situs kubur kuna Leran, Dinas Kebudayaan dan Pariwisata Kabupaten Rembang, serta masyarakat Leran dan Binangun di Kab. Rembang yang telah membantu penelitian di situs tersebut sehingga berjalan lancar. Tidak lupa, penulis mengucapkan terimakasih atas bimbingan dan nasihat Ibu Dr. Erwiza Erman, M.A sejarawan LIPI- khususnya dalam proses penulisan karya ini. Selain itu juga ucapan terimakasih kepada editor dan dua mitra bestari jurnal Berkala Arkeologi, sehingga tulisan ini dapat terbit dengan baik. 


\section{DAFTAR PUSTAKA}

Albrow, M. dan King, E. 1990. Globalization, knowledge and society: readings from international sociology. London: Sage Pub.

Al-Rodhan, Nayef RF, dan Gérard Stoudmann. 2006. "Definitions of globalization: A comprehensive overview and a proposed definition." Program on the Geopolitical Implications of Globalization and Transnational Security 6, 1-21.

Ardika, I Wayan dan Peter Bellwood. 1991. "Sembiran: the Beginnings of Indian Contact with Bali”, Antiquity No. 65 (247): 221-232.

Armelagos, G.J., Carlson, D.S., dan van Gerven, D.P. 1982. "The Theoretical Foundations and Development of Skeletal Biology", in F. Spencer (ed) A History of American Physical Anthropology 1930-1980, 305-328. Edited by F. Spencer. New York: Academic Press. New York: Academic Press.

Bauman, Z. 1998. "On glocalization: Or globalization for some, localization for some others". Thesis Eleve, 54 (1): 37-49.

Bayly, C.A. 2005. "From archaic globalization to international networks, circa 1600-2000". Interactions: transregional perspectives on world history, hlm. 14-29.

Bellwood, Peter. 2013. First Migrants: Ancient Migration in Global Perspective. Willey Blackwell.

Bellwood, Peter. 2000. Prasejarah Kepulauan Indo-Malaysia, Edisi Revisi, Jakarta: PT. Gramedia Pustaka Utama.

Bergman, R.A.M. dan The, T.H. 1955."The length of the body and long bones of the Javanese". Documenta de Medecina Geographica et Tropica, 7, 197214.

Bintarti, D.D. 2000. "More on Urn Burials in Indonesia", Bulletin of the Indo-Pacific Prehistory Association, No. 19 Vol.3: 73-75.

Blust, Robert. 1985. "The Austronesian homeland: a linguistic perspective", Asian Perspectives 26 (1): 45-67.

Buikstra, J.E., dan Ubelaker, D.H. 1994. "Standards for Data Collection from Human Skeletal Remains", Arkansas Archaeological Survey Report Number 44, Arkansas.

Calo, A., Prasetyo, B., Bellwood, P., Lankton, J.W., Gratuze, B., Pryce, T.O., Reinecke, A., Leusch, V., Schenk, H., Wood, R. and Bawono, R.A. 2015. "Sembiran and Pacung on the north coast of Bali: a strategic crossroads for early trans-Asiatic exchange". Antiquity, 89 (344): 378-396. 
Dorléans, Bernard. 2006. Orang Indonesia dan orang Prancis: dari abad XVI sampai dengan abad XX. Jakarta : Kepustakaan Populer Gramedia.

Dwiyanto, Djoko. 1993. "Perpajakan pada Masa Majapahit", dalam Sartono Kartodirjo dkk (eds), 700 Tahun Majapahit: Suatu Bunga Rampai , 217-234. Dinas Pariwisata Prov. Dati I Jawa Timur.

Enoki K., Dahlberg A.A. 1958. "Rotated maxillary central incisors", Orthod J Jpn 17, 157.

Flynn, D.O. dan Giráldez, A. 2006. "Globalization began in 1571". Globalization and Global History, 232-247.

Foltz, R. 2016. Religions of the Silk Road: Premodern patterns of globalization. Springer.

Gills, B.K. dan Thompson, W.R. 2006. Globalization and global history. Psychology Press.

Glover, lan. 1990. "Early Trade Between India and Southeast Asia: a Link in the development of a World trading System", Occasional Paper, No. 16.

Gonzalo, A. H. 2006. "Arqueología y Globalización. El problema de la definición del" otro" en la Postmodernidad/Archaeology and Globalization". The problem on the definition of the" other" in Post-modernity. Complutum, 17, 221-234.

Hammer, R.., D. A. T. Harper, and P. D. Ryan. 2001. "PAST: Paleontological Statistics Software Package for Education and Data Analysis-"Palaeontol. Electron. 4: 9.

Hanihara K., Tanaka T., Tamada M. 1970. "Quantitative analysis of the shovelshaped character in the incisors", J Anthropol Soc Nippon 78: 90-93.

Heekeren, H.R. van. 1958. "The Bronze-Iron Age of Indonesia", Verhandelingen van het Koninklijk Instituut voor Tall-, Land-, en Volkenkunde, Deel XXII, The Hague: Martinus Nijhoff.

Hoerder, D. 2002. Cultures in Contact: World Migrations in the Second Millennium (Comparative and International Working-Class History), London: Duke University Press.

Holland, Steven M. 2006. Cluster Analysis. University of Georgia.

Jørgensen K.D. 1955. "The Dryopithecus pattern in recent Danes and Dutchmen", J Dent Res 34: 195-208.

Kasnowihardjo, Gunadi. 2013. "Temuan Rangka Manusia Austronesia di Pantura Jawa Tengah: "Sebuah Kajian Awal", Berkala Arkeologi : 1-12. 
Kumar, K. 2009. From post-industrial to post-modern society: New theories of the contemporary world. John Wiley \& Sons.

Larsen, C. S. 1997. Bioarchaeology: Interpreting Behavior from the Human Skeleton, Cambridge: University Press.

Lewellen, T.C. 2002. The anthropology of globalization: Cultural anthropology enters the 21st century. Greenwood Publishing Group.

Lombard, Denys. 2005. Nusa Jawa Silang Budaya, Jilid 3 Warisan KerajaanKerajaan Konsentris, Jakarta: Gramedia.

Lovejoy, C.O. 1985. "Dental wear in the Libben population: Its functional pattern and role in the determination of adult skeletal age at death". American Journal of Physical Anthropology 68: 47-56.

Manguin, Pierre-Yves. 2009. "Southeast Sumatra in Protohistoric and Srivijaya Times: Upstream-Downstream Relations and the Settlement of the Peneplain", From Distant Tales: Archaeology and Ethnohistory in the Highlands of Sumatra, 434-484.

Manguin, Pierre-Yves dan Agustijanto Indradjaja. 2011. "Batujaya Site: New Evidence of Early Indian Influence in West Java", in Pierre-Yves Manguin et al., (eds.), Early Interactions between South and Southeast Asia, Reflections on Cross Cultural Exchange, 113-136. Singapore: Institute of Southeast Asian Studies.

Martin R, dan Saller K. 1957. Lehrbuch der Antropologie. Stuttgart: Gustav Fischer Verlag.

Matsumura, H. dan Oxenham, M.F. 2014. "Demographic Transitions and Migration in Prehistoric East/Southeast Asia Through the Lens of Nonmetric Dental Traits", American journal of physical anthropology, 155 (1): 45-65.

Meilink-Roelofsz, M.A.P. 2012. Asian Trade and European Influence in the Indonesian Archipelago between 1500 and about 1630. Amsterdam: Springer.

Paul, K.A. 2011. "Bronze Age Aegean Influence in the Mediterranean: Dissecting Reflections of Globalization in Prehistory", Doctoral dissertation, The George Washington University.

Pietrusewsky, M. 2000. "Metric analysis of skeletal remains: methods and applications." Biological Anthropology of the Human Skeleton, 375-415.

Noerwidi, Sofwan. 2012a. "The significant of the Holocene human skeleton Song Keplek 5 in the history of human colonization of Java: A comprehensive morphological and morphometric study", International Master Thesis in Quaternary and Prehistory, Paris: MNHN. 
2012b. "Rekonstruksi Aspek Biologis dan Kultural Rangka Manusia Holosen, Song Keplek 5”, Berkala Arkeologi Vol. 32, No. 2 (2012): 137-151.

2014. "Beberapa Aspek Biokultural Rangka Manusia dari Situs Kubur Kuna Leran, Rembang, Jawa Tengah”, Amerta Vol. 32 No. 2, 2014.

O'Rourke, K.H. dan Williamson, J.G. 2001. Globalization and history: the evolution of a nineteenth-century Atlantic economy. Mit Press.

Prasetyo, Bagyo. 1994/1995. "Laporan penelitian situs Plawangan, Rembang, Jawa Tengah (1980-1993)", Berita Penelitian Arkeologi No. 43, Jakarta: Proyek Penelitian Purbakala.

Priswanto, Hery. 2012. "Orang-orang Asing di Majapahit", dalam Inajati Adrisijanti (ed), Majapahit: Batas Kota dan jejak Kejayaan di Luar Kota, 22-34. Yogyakarta: Balai Arkeologi Yogyakarta.

Reid, A. 1993. Southeast Asia in the Age of Commerce, 1450-1680: Expansion and crisis (Vol. 2). Yale University Press.

Rooney, Dawn F. 1993. Betel Chewing Traditions in South-East Asia, Oxford: University Press.

Saheki M. 1958. "On the heredity of the tooth crown configuration studied in twins", Acta Anat Nipponica 33, hlm. 456-470.

Sather, Clifford. 1995. "Sea Nomads and Rainforest Hunter-Getherers: Foraging Adaptations in the Indo-Malaysian Archipelago", dalam Peter Bellwood, James J. Fox dan Darrell Tryon, (eds). The Austronesians: Historical and Comparative Perspective, 17-38. Canberra: ANU printing service.

Scott, G.R. 1973. "Dental morphology: A genetic study of American White families and variation in living Southwest Indians". PhD dissertation, Arizona State University.

Soejono, R.P. 1977. "Sistem-sistem penguburan pada akhir masa prasejarah di Bali", Doctoral Thesis, University of Indonesia.

Spriggs, Matthew. 2000. "Out of Asia: The Spread of Southeast Asian Pleistocene and Neolitic Maritime Culture in Island Southeast Asia and the Western Pacific", dalam Sue O'Connor \& Peter Veth (eds). East of Wallace's Line, Studies of Past and Precent Maritime Culture of the IndoPacific Region, Roterdam: A.A. Balkema.

Sukendar, Haris dan Rokhus Due Awe. 1981. "Laporan Penelitian terjan dan Plawangan Jawa Tengah Tahap I dan II", Berita Penelitian Arkeologi No. 27, Jakarta: Proyek Penelitian Purbakala. 
Sukendar, Haris., I. Panggabean., R.D. Awe. 1982. "Laporan Survei Pandeglang dan Ekskavasi Anyer, Jawa Barat, 1979", Berita Penelitian Arkeologi No. 28, Jakarta: Proyek Penelitian Purbakala.

Suzuki M. dan Sakai T. 1973. The Japanese dentition, Matsumoto: Shinshu Univ Press.

Tanudirjo, Daud Aris. 2006. "The dispersal of Austronesian-speaking people and the ethnogenesis of Indonesian people", Austronesian Diaspora and the Ethnogenesis of People in Indonesian Archipelago, 83-98.

Tryon, Darrell. 1995. "Proto-Austronesian and The Major Austronesian Subgroups", dalam Peter Bellwood, James J. Fox dan Darrell Tryon, (eds). The Austronesians: Historical and Comparative Perspective, 17-38. Canberra: ANU printing service.

Turner CG II, Nichol CR, Scott GR. 1991. "Scoring procedures for key morphological traits of the permanent dentition: The Arizona State University dental anthropology system", dalam Kelly M.A., Larsen C.S., (eds)., Advances in dental anthropology, 13-3. New York: Wiley-Liss.

Wahyudi, Wany Raharjo dan Kuswanto."Kajian Konsep Open-Air Museum : Studi Kasus Kawasan Cagar Budaya Trowulan". Berkala Arkeologi Vol. 34 No. 1 (2014): 65-84.

White, T.D., dan Folkens, P.A. 2005. The Human Bone Manual. Elsevier Academic Press. 


\section{LAMPIRAN}

Tabel 1. Variabel Non-Metrik Gigi Manusia

\begin{tabular}{|c|c|c|c|c|c|}
\hline Trait & Tooth & Description & Criteria & Presence & Remark \\
\hline Shoveling & UI1, UI2 & Hanihara et al., 1970 & $\begin{array}{l}\text { Depth of Lingual Fossa } \\
\text { (DFL) }\end{array}$ & $\begin{array}{l}\text { DLF }>= \\
0.5 \mathrm{~mm}\end{array}$ & (ASUDA 3-7) \\
\hline Double shoveling & UI1, UI2 & Suzuki and Sakai, 1973 & $\begin{array}{l}\text { (none }),+(\text { weak }),++(\text { moder } \\
\text { ate }),+++(\text { strong })\end{array}$ &,+++++ & (ASUDA 3-6) \\
\hline Dental tubercle & UI1, UI2 & Turner II et al., 1991 & $\begin{array}{l}0 \text { (none), } 1 \text { (faint), } 2 \text { (trace), } \\
3 \text { (strong ridging) - } \\
6 \text { (strong cusp) }\end{array}$ & $3-6$ & \\
\hline Spine & UI1 & 0:none 1:present & $\begin{array}{l}0(\text { none }), 1 \text { (single }) \\
2(\text { double }), 3 \text { (triple })\end{array}$ & $1-3$ & \\
\hline $\begin{array}{l}\text { Interruption } \\
\text { groove }\end{array}$ & UI2 & Turner II et al., 1991 & $\begin{array}{l}0 \text { (none) }, \mathrm{M}(\text { mesial }) \\
\text { Med(central }), \mathrm{D}(\text { distal })\end{array}$ & M,D,MD,Med & \\
\hline Winging (bilateral) & UI1 & $\begin{array}{l}\text { Enoki and Dahlberg, } \\
1958\end{array}$ & $\begin{array}{l}0 \text { (straight), } 1 \text { (counter } \\
\text { wing), 2(bilateral wing), } \\
\text { 3(uni-counter wing), } \\
\text { 4(uni-lateral wing) }\end{array}$ & 1 & \\
\hline De Terra's tubercle & UP1 & Saheki, 1958 & $\begin{array}{l}0 \text { (none }),+(\text { faint ridging }), \\
++(\text { small cusp }),+++(\text { large } \\
\text { cusp })\end{array}$ &,+++++ & \\
\hline Double roots & UP1, UP2 & Turner II et al., 1991 & $\begin{array}{l}\text { 1(single), 2(double), } \\
\text { 3(triple) }\end{array}$ & $2-3$ & \\
\hline Carabelli's trait & UM1 & Dahlberg's P-plaque & $\begin{array}{l}a(\text { none }), b \text { (furrow), c(pit), } \\
\text { d(double grooves), e(Y- } \\
\text { shape), f(small cusp), g- } \\
\text { h(large cusp) }\end{array}$ & $\mathrm{d}-\mathrm{h}$ & (ASUDA 3-7) \\
\hline $\begin{array}{l}\text { Hypocone } \\
\text { reduction }\end{array}$ & UM2 & Dahlberg's P-plaque & $\begin{array}{l}\text { 3(none), 3+(faint cusp), 4- } \\
\text { (small cusp), 4-(large } \\
\text { cusp) 4(full size cusp) }\end{array}$ & 3 and $3+$ & (ASUDA 0-1) \\
\hline Sixth cusp & LM1 & Turner II et al., 1991 & $\begin{array}{l}0 \text { (none), } 1(\text { small cusp)- } \\
5 \text { (large cusp) }\end{array}$ & $1-5$ & \\
\hline Seventh cusp & LM1 & Turner II et al., 1991 & $\begin{array}{l}0 \text { (none), } 1 \text { (faint), } 2 \text { (small } \\
\text { cusp)-4(large cusp) }\end{array}$ & $2-4$ & \\
\hline Protostylid & LM1 & Dahlberg's P-plaque & $\begin{array}{l}0 \text { (none), } \mathrm{p} \text { (pit), } 1 \text { (curved } \\
\text { groove), } 2 \text { (slight } \\
\text { secondary } \\
\text { groove),3(secondary } \\
\text { groove)-5(free apex) }\end{array}$ & $3-5$ & (ASUDA 5-6) \\
\hline Deflecting wrinkle & LM1 & Turner II et al., 1991 & $\begin{array}{l}0 \text { (none), } 1 \text { (faint), } \\
\text { 2(moderately deflect), } \\
\text { 3(L-shape) }\end{array}$ & $2-3$ & \\
\hline Groove pattern Y & LM1 & Jørgensen, 1955 & $\mathrm{Y},+, \mathrm{X}$ & $\mathrm{Y}$ & \\
\hline Groove pattern $\mathrm{X}$ & LM2 & Jørgensen, 1955 & $\mathrm{Y},+, \mathrm{X}$ & $\mathrm{X}$ & \\
\hline $\begin{array}{l}\text { Number of cusps } \\
\text { (hypoconulid } \\
\text { reduction) }\end{array}$ & LM2 & Turner II et al., 1991 & $\begin{array}{l}\text { 4(no hyld), } 5 \text { (hyld } \\
\text { present), } 6 \text { (6th cup } \\
\text { present) }\end{array}$ & 4 & \\
\hline
\end{tabular}

Sumber : Matsumura dan Oxenham, 2014: 8 


\section{LAMPIRAN}

Tabel 2. Perbandingan Morfologi Gigi-geligi Manusia Leran dengan Populasi di Sekitarnya

\begin{tabular}{|c|c|c|c|c|c|c|}
\hline No. & Trait & Tooth & Leran n & Leran \% & Population & $\%$ \\
\hline 1. & Shoveling & UI1 & 5 & 0,20 & Andaman & 0,27 \\
\hline 2. & Shoveling & UI2 & 4 & 0,75 & Aeta & 0,76 \\
\hline 3. & Double shoveling & UI1 & 5 & 0 & Early - Late Holocene & 0 \\
\hline 4. & Double shoveling & UI2 & 4 & 0 & Early - Late Holocene & 0 \\
\hline 5. & Dental tubercle & UI1 & 5 & 0 & Dayak & 0 \\
\hline 6. & Dental tubercle & UI2 & 4 & 0,50 & Noen U Loek & 0,47 \\
\hline 7. & Spine & UI1 & 6 & 0 & Bunun & 0,07 \\
\hline 8. & Interruption groove & UI2 & 4 & 0,75 & Noen U Loek & 0,68 \\
\hline 9. & Winging (bilateral) & UI1 & 4 & 0 & Early - Late Holocene & 0 \\
\hline 10. & De Terra's tubercle & UP1 & 5 & 0,60 & Jundushan (?) & 0,59 \\
\hline 11. & Double roots & UP1 & 5 & 0,40 & Hainan & 0,40 \\
\hline 12. & Double roots & UP2 & 5 & 0 & Metal Age & 0 \\
\hline 13. & Carabelli's trait & UM1 & 6 & 0 & Early Holocene & 0,09 \\
\hline 14. & Hypocone reduction & UM2 & 6 & 0,67 & $?$ & \\
\hline 15. & Sixth cusp & LM1 & 7 & 0,43 & Australo-Melanesian & 0,45 \\
\hline 16. & Seventh cusp & LM1 & 7 & 0,57 & $?$ & \\
\hline 17. & Protostylid & LM1 & 9 & 0 & Khok Phanom Di & 0 \\
\hline 18. & Deflecting wrinkle & LM1 & 7 & 0,43 & Early - Late Holocene & 0,50 \\
\hline 19. & Groove pattern Y & LM1 & 7 & 1,00 & Early - Late Holocene & 0,88 \\
\hline 20. & Groove pattern $X$ & LM2 & 9 & 0,67 & Atayal & 0,50 \\
\hline 21. & $\begin{array}{l}\text { Number of cusps } \\
\text { (hypoconulid reduction) }\end{array}$ & LM2 & 9 & 0,56 & Early - Late Holocene & 0,60 \\
\hline
\end{tabular}

Sumber: Hasil Analisis Penulis 


\section{LAMPIRAN}

Distance
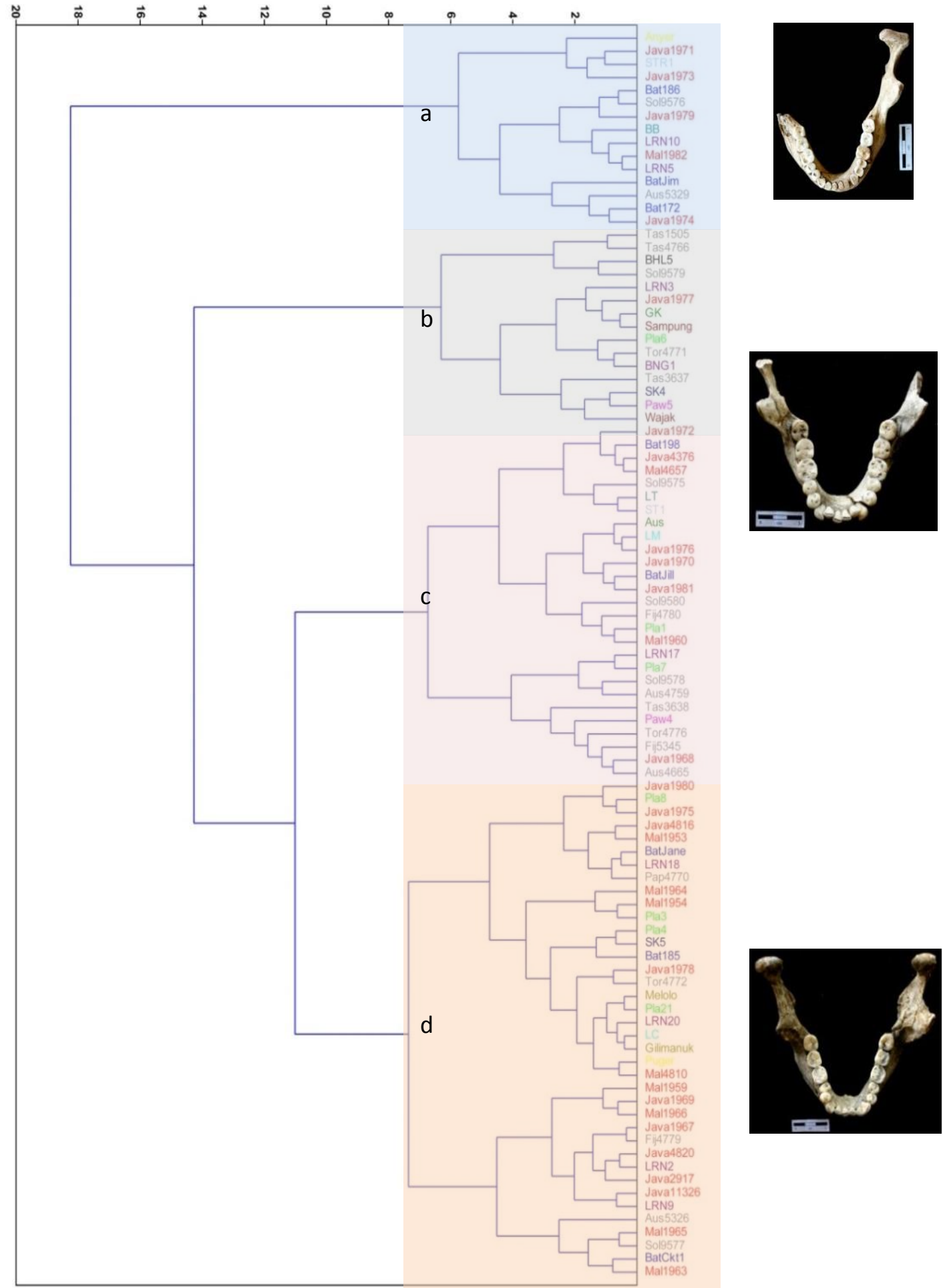

Gambar 7. Cluster Analysis Posisi Manusia Leran dalam Perbandingannya dengan Populasi di Asia Tenggara

(Sumber: Hasil Analisis Penulis) 